Site Carpentry and Advanced Joinery 
By the same author

Part I: Carpentry, Joinery and Machine Woodworking (Wood Trades Part 1)

Part II: Carpentry and Joinery (Wood Trades Part 2) 


\section{SITE CARPENTRY AND \\ ADVANCED JOINERY}

A. B. Emary

F.I.O.C. 
(C) A. B. Emary 1985

Reprint of the original edition 1985

All rights reserved. No part of this publication

may be reproduced or transmitted, in any form

or by any means, without permission

First published 1985 by

Higher and Further Education Division

MACMILLAN PUBLISHERS LTD

Houndmills, Basingstoke, Hampshire RG21 $2 X S$ and London

Companles and representatives throughout the world

Typeset in Great Britain by

STYLESET LIMITED

Warminster, Wiltshire

\section{British Library Cataloguing in Publication Data}

Emary, A.B.

Site carpentry and advanced joinery.

$\begin{array}{ll}\text { 1. Carpentry } 2 \text {. Joinery } & \end{array}$

I. Title

694 TH5604

ISBN 978-1-349-06903-3

ISBN 978-1-349-06901-9 (eBook)

DOI 10.1007/978-1-349-06901-9 


\section{CONTENTS}

Preface

1 On-site Work

2 Timbering to Excavations

3 Supports to Buildings

4 Gantries

5 Formwork for Concrete

6 Foot Bridges

7 Centres to Arches

8 Roofs

9 Dormer and Eyebrow Windows

10 Open-type Roof Trusses

11 Storage Shed Roofs

12 Roof Lights, Ventilators and Domes $v i$

1

13 Steeples

4

14 The Manufacture of Joinery Items

61

8

15 Doors, Frames and Linings

64

16

16 Frames and Linings

19

17 Windows and Window Ventilators

78

26

18 Panelling

87

30

19 Counter Construction

20 Laminated Components

93

37

21 Church Furniture

96

41

22 Stairs

45

23 Handrailing

116

49 


\section{PREFACE}

The primary aim of this book is to give students of carpentry and joinery an insight into a more advanced knowledge of their work than that given in Part I (Carpentry, Joinery and Machine Woodworking, Wood Trades Part 1) and Part II (Carpentry and Joinery, Wood Trades Part 2).

Secondly, its aim is to assist in the obtaining of qualifications in the examinations set by the Institute of Carpenters, the City and Guilds of London Institute and the regional examining bodies.

The subjects of Site Carpentry and Purpose Made Joinery have been brought together in one book to assist those who are aiming for qualifications in both subjects and who want to obtain guidance at a reasonable cost. It is obvious that the syllabuses of the examining bodies cannot be fully covered in a book of this size. Hence subjects that the author considers best taught in the classroom are not included. These aspects, and the further development of subjects that are covered within these pages, are best acquired by following a course of study at a local technical college.

As many drawings as possible have been included in the book and the text has been written in simple terms and as briefly as possible. The main purpose for presenting the text in its briefest form is to encourage further research into each of the subjects. Readers, especially students at Colleges, must realise that some of the surest ways of learning are visits to the library, discussions in class and the asking of questions. Teachers, I am sure, already know this and should encourage their students along these lines. Teachers should also emphasise to their students the importance of reading the text as well as studying the drawings; it is the author's experience that students tend to ignore the written word and rely solely on the drawings to give them the information they require. This is a great mistake, as most people will recognise.

Some of the subjects that are included in the advanced syllabuses of most examining bodies, such as scaffolding, setting out and levelling, woodcutting machinery etc., have already been covered in Part II; others are developed further in this book in order to cover more advanced examples of the work. 